\title{
Evaluating the impact of thermal variations on the penetration test parameters.
}

\author{
G. Franchomme, S. Rosin \& F. Masrouri
}

LEMTA (CNRS, UMR 7563) 2 avenue de la Forêt de Haye, BP 160, F-54504, Vandoeuvre-lès-Nancy Cedex, France

\begin{abstract}
Geostructures or thermo-active foundations consist in establishing a thermal exchange with the ground directly through building foundations or other structures buried in the soil. Geostructures may extract or inject energy from or into the ground to produce heating or cooling in a building. Their cost is currently about 30\% lower than the usual geothermal solutions using vertical probes. However, adapting foundation piles in whole or in part to energy piles brings questions on the impact of the temperature variations on the geotechnical parameters and load-bearing capacity of the soil. The bearing capacity calculations of deep foundations are currently based on penetrometer testing results. In this study, a high resolution mini-penetration test, adapted from current static penetration test, was developed to characterize laboratory samples.

A kaolinite/sand mixture was prepared to test a material in an intermediate state between a cohesive and a non-cohesive soil. Samples were performed at various water contents (9 to 19\%) and dry densities (1.58 to $\left.1.91 \mathrm{Mg} / \mathrm{m}^{3}\right)$ and submitted to linear and cyclic thermal stresses $\left(1\right.$ to $\left.50^{\circ} \mathrm{C}\right)$. Results showed a high repeatability of these tests. Two parameters were measured: the cone tip resistance $\left(q_{c}\right)$ and the sleeve friction $(f s)$. These parameters highly depend on the water content of the material. We showed that the temperature variations with constant water content did not affect the measured shear stress parameters. The proposed penetration tests can be carried out as a quick and easy-to-use test to compare the impact of thermal stresses on the soil parameters.
\end{abstract}

\section{INTRODUCTION}

Thermo-active geostructures consist in adding to the classical sustainable function of geostructure a second function of thermal exchange with the ground. These systems use the subsurface as a heat source or as a cooling source. A liquid circulates through a ground circulation closed-loop system integrated to the geostructure. Geostructures may be piles, barrettes, diaphragm walls, tunnel linings, basement slabs or walls (Fromentin et al., 1999, Laloui et al., 2003, Brandl, 2006). The standard use of thermoactive foundations modifies the current ground temperature $\left(12^{\circ} \mathrm{C}\right.$ ) in a scale of 1 to $30^{\circ} \mathrm{C}$ (Peron and Laloui, 2011). Geo-exchange systems in ground structures require consideration of the complex interaction between temperature change and induced stresses or deformations, which may affect building performance (McCartney et al., 2010).

Foundation piles work thanks to the combination of two effects: the cone tip resistance and the sleeve friction along the pile. The sleeve friction can be associated with the shear resistance. The shear resis- tance is the relative resistance of the ground that goes against the sliding caused by a load. The impact of temperature on shear resistance is complex. Some authors such as Mitchell (1964), Sherif and Burrous (1969), de Bruyn and Thimus (1996), Lingnau et al. (1996) and Wiebe et al. (1998) showed that ground heating leads to a decreasing of shear resistance whereas Noble and Demirel (1969), Houston et al. (1985), Tanaka et al. (1996) and Cekerevac and Laloui (2004) noticed the opposite results. In fact, heating and loading cause opposite effects. On the one hand, the heating causes decreasing of the viscosity of the interstitial water. In consequence, the resistance between aggregate decreases as well as the shear resistance. On the other hand, the heating of a material under a mechanical stress causes a densification of the ground which results in to increase contacts between aggregates. In consequence, the resistance between aggregate increases as well as the shear resistance. So the two kinds of conclusions found in published works are due to a combination of these two effects in different soils.

Considering that thermo-active foundations may be built in a large extent of soil nature and given the difficulty in forecasting how a temperature variation 
can affect the shear resistance of a material, it seems necessary to develop a quick and easy-to-use test to compare the impact of a thermal stress on the soil parameters. In this study, a high resolution minipenetration test was developed. The method supplies parameters close to the penetrometer test currently used to calculate the bearing capacity of piles. The aim is to define quickly the impact of a thermal stress on the shear resistance of different materials.

In this study, the mini-penetration test was first presented then tested on a kaolinite and fine sand mixture. Several samples were prepared at the proctor optimum and and submitted to temperature from 1 to $50^{\circ} \mathrm{C}$, which included the maximal variation of the soil temperature for a current use of thermal piles. Then, the main results were summarized. Finally, conclusions were made on the impact of the tested temperatures on the chosen material and the possible prospects of the use of the mini-penetration test.

\section{MATERIAL AND METHODS}

\subsection{Preparation and basic characterization of the samples}

The tested material was a mixture of $50 \%$ of kaolinite Argirec B24 from Charente basin and 50\% of Hostun sand HN 38 (France), prepared in laboratory. The materials were dried separately at least 24 hours in an oven $\left(60^{\circ} \mathrm{C}\right)$ then mechanically mixed in desired proportion. Water was added to obtain different initial water contents comprised between 9 and $19 \%$. Then the mixture was packed in hermetic bags and left for homogenization at least 24 hours (Table 1).

Table 1: Water content determines after the compaction of the sample $\left(w_{i}\right)$ and after the penetration test $\left(w_{f}\right)$, dry density $\left(\rho_{d}\right)$ and temperature $(T)$ of each sample.

\begin{tabular}{|l|c|c|c|c|}
\hline Test & $w_{i}(\%)$ & $\rho_{d}\left(\mathrm{Mg} / \mathrm{m}^{3}\right)$ & $T\left({ }^{\circ} \mathrm{C}\right)$ & $w_{f}(\%)$ \\
\hline E1 & 9.3 & 1.60 & 20 & 9.3 \\
\hline E2 & 11.3 & 1.74 & 20 & 11.3 \\
\hline E3 & 11.9 & 1.82 & 20 & 11.9 \\
\hline E4,E*4 & 12.3 & 1.87 & 20 & 12.3 \\
\hline E5, E*5 & 13.0 & 1.88 & 20 & 13.0 \\
\hline E6 & 13.2 & 1.89 & 20 & 13.2 \\
\hline E7, E*7 & 14.2 & 1.85 & 20 & 14.2 \\
\hline E8, E*8 & 15.1 & 1.82 & 20 & 15.1 \\
\hline E9, E*9 & 16.9 & 1.73 & 20 & 16.9 \\
\hline E10, E*10 & 18.5 & 1.66 & 20 & 18.5 \\
\hline E11, E*11 & 13.5 & 1.90 & 1 & 13.4 \\
\hline E12, E*12 & 13.5 & 1.90 & 30 & 13.2 \\
\hline E13 & 13.4 & 1.87 & 50 & 12.5 \\
\hline
\end{tabular}

The liquid limit of the material $\left(L_{L}\right)$ was $26.9 \%$, the plastic limit $\left(P_{L}\right)$ was $15.4 \%$ and the plasticity index $(P I)$ was 11.5 .

The particle size distribution was determined using a Laser Fritsch analysette 2@ (Figure 1).

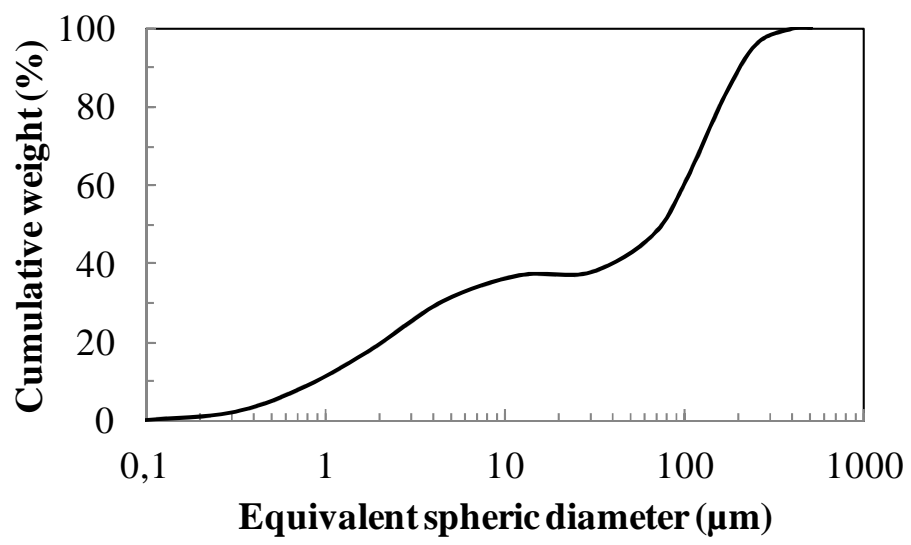

Figure 1: Particle size distribution of kaolinite sand mixture.

The material was compacted in 6 layers in a mold of $152 \mathrm{~mm}$ in diameter and $152 \mathrm{~mm}$ in height. The applied energy was the same than that used in the Proctor method. The compaction in 6 layers permitted to ensure the homogeneity of the material in the mold (Table 1). The obtained compaction curve was superimposed to the Standard Proctor curve (Figure 2). The optimum water content was $13 \%$ and the maximum dry density was $1.88 \mathrm{Mg} / \mathrm{m}^{3}$ (Figure 2).

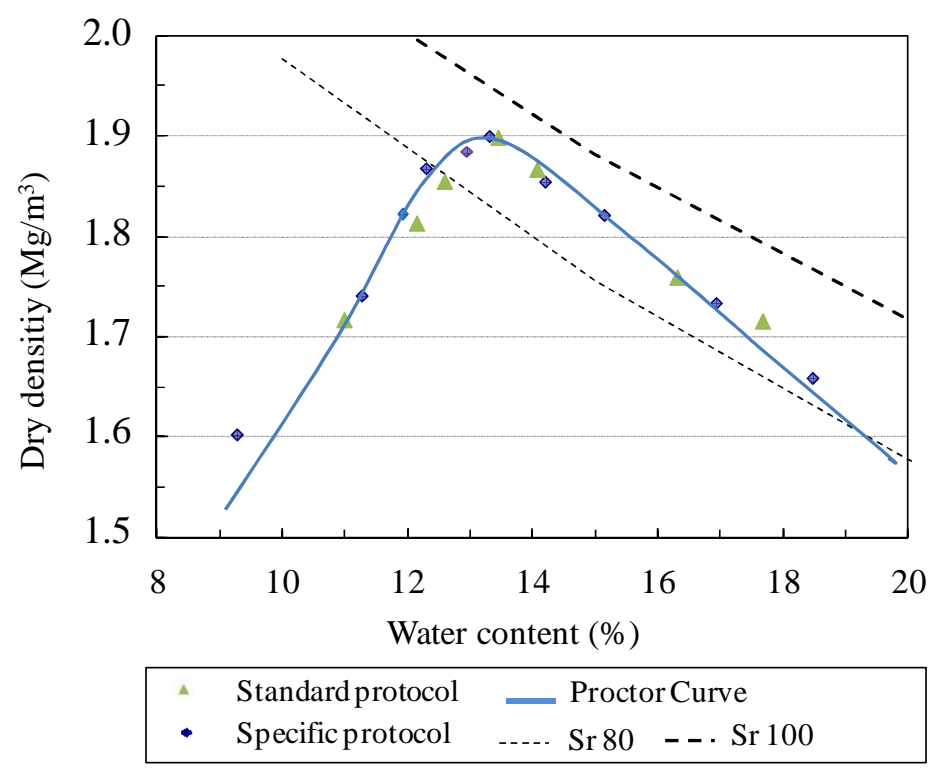

Figure 2 : Comparison between the Proctor curve and the specific compaction curve of the material. $\mathrm{Sr}$ : Saturation rate. 


\subsection{Thermal cure}

A thermal curing at 1,30 or $50{ }^{\circ} \mathrm{C}$ was applied to a sample equipped with a thermal sensor to determine the minimal duration of thermal curing (Table 2). The initial temperature of the sample was $20^{\circ} \mathrm{C}$.

Table 2 : Parameters of the thermal cure protocol

\begin{tabular}{|l|l|l|l|}
\hline $\begin{array}{l}\text { Climatic chamber } \\
\text { temperature }\left({ }^{\circ} \mathrm{C}\right)\end{array}$ & 1 & 30 & 50 \\
\hline $\begin{array}{l}\text { Duration of the } \\
\text { thermal cure }(\mathrm{h})\end{array}$ & $9 \mathrm{~h} 20$ & $4 \mathrm{~h} 20$ & $12 \mathrm{~h} 50$ \\
\hline Sample temperature $\left({ }^{\circ} \mathrm{C}\right)$ & 1.5 & 29.3 & 48.8 \\
\hline
\end{tabular}

\subsection{Mini penetration test}

The mini-penetration test is a laboratory test adapted from the normalized static penetration test (NF P94113, AFNOR, 1996). Our test consisted of pushing a probe with a cone having a $60^{\circ}$ apex continuously at $30 \mathrm{~mm} / \mathrm{s}$ into each sample (Figure 3). Two stainless steel probes, respectively named $\mathrm{P} 1$ and $\mathrm{P} 2$ were used (Figure 3$)$. The length $(250 \mathrm{~mm})$ as well as the angle $\left(60^{\circ}\right)$ and the maximal external diameter (12 $\mathrm{mm}$ ) of the cones are similar. Diameters of the probes differ from $10 \mathrm{~mm}$ for P1 to $12 \mathrm{~mm}$ for P2. The maximum penetration length of each probe is $100 \mathrm{~mm}$. The cone tip resistance was measured with $\mathrm{P} 1$, whereas using $\mathrm{P} 2$, a combination of the cone tip resistance and the sleeve friction was obtained.

At the equilibrium temperature, 3 mini-penetration tests were carried out in each mold. The position of each penetration test is fixed to avoid edge effects (Figure 4).

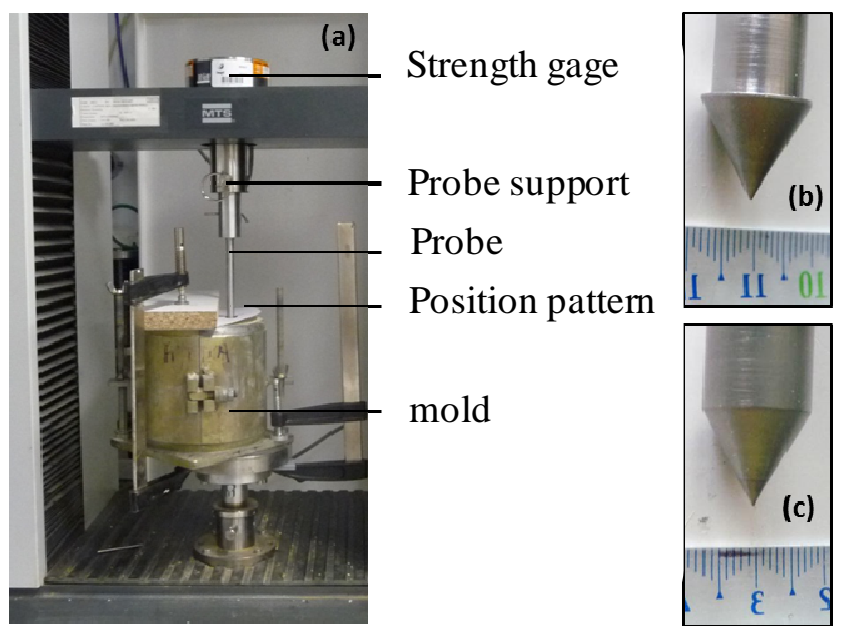

Figure 3: a. Mini-penetration test with tractioncompression machine and probes for minipenetration test (b. P1; c. P2).
Three penetration velocities were tested: $1 \mathrm{~mm} / \mathrm{min}$, $30 \mathrm{~mm} / \mathrm{min}$ and $90 \mathrm{~mm} / \mathrm{min}$. The velocity of the probe determined the test duration. This duration should be minimized to avoid the changes of water content of the samples. Preliminary tests showed noimpact of probe penetration velocity on the measured parameters. For that reason an intermediate speed of $30 \mathrm{~mm} / \mathrm{min}$.

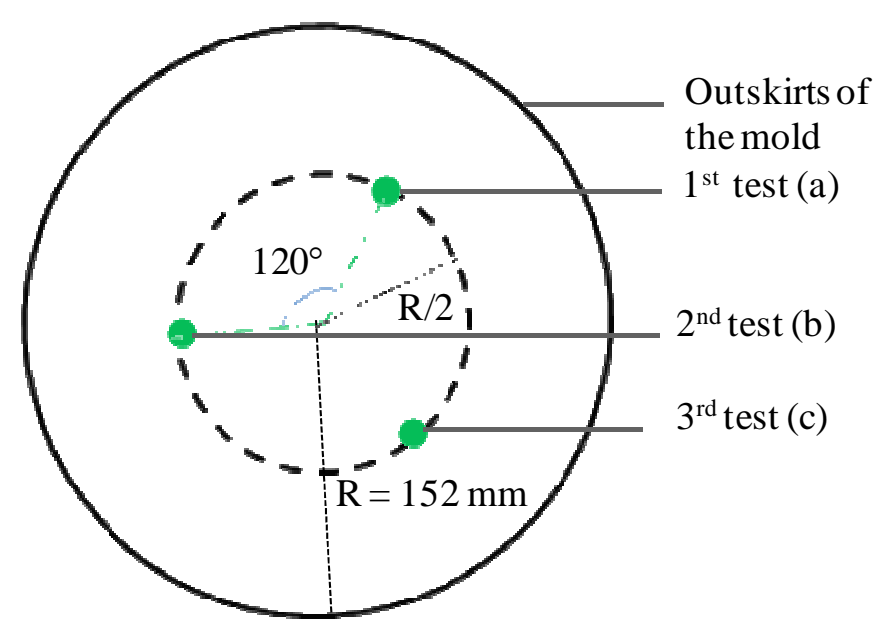

Figure 4: Position of penetration tests in the mold.

\section{RESULTS}

\subsection{Mini-penetration curves typology}

The penetration curves obtained by $\mathrm{P} 1$ and $\mathrm{P} 2$ probes were respectively named $\mathrm{E}$ and $\mathrm{E}^{*}$ tests. The variation of the total strength versus depth is shown on Figure 5. In the first part of the curves $(a)$, the apex of the probe penetrated into the soil, this part is similar for two probes as the angle and the diameter of the cone apex are identical. Part $b$ is peculiar to the use of P1. As the friction sleeve was not measured, the strength variation was constant for a homogeneous soil. Part $c$ is peculiar to $\mathrm{P} 2$. The strength increased as the probe enters in contact with the soil. The cone tip resistance $\left(q_{c}\right)$ was calculated by averaging the strength values obtained on the linear part (b) of P1 test. Equations 1 and 2 allowed the transformation of the measured stresses in a resistance.

$q_{c}=F_{c} /\left(\pi R_{l}^{2}\right)$

$f_{s}=(F t-F c) /\left(2 \pi R_{2}(L-L p)\right)$

where $F_{C}$ is the cone tip strength ; $R_{l}$ is the radius of the cone apex, $R_{2}$ is the probe radius; $f s$ is the sleeve friction; $L$ is the penetration length and $L p$ is the height of the cone apex. 


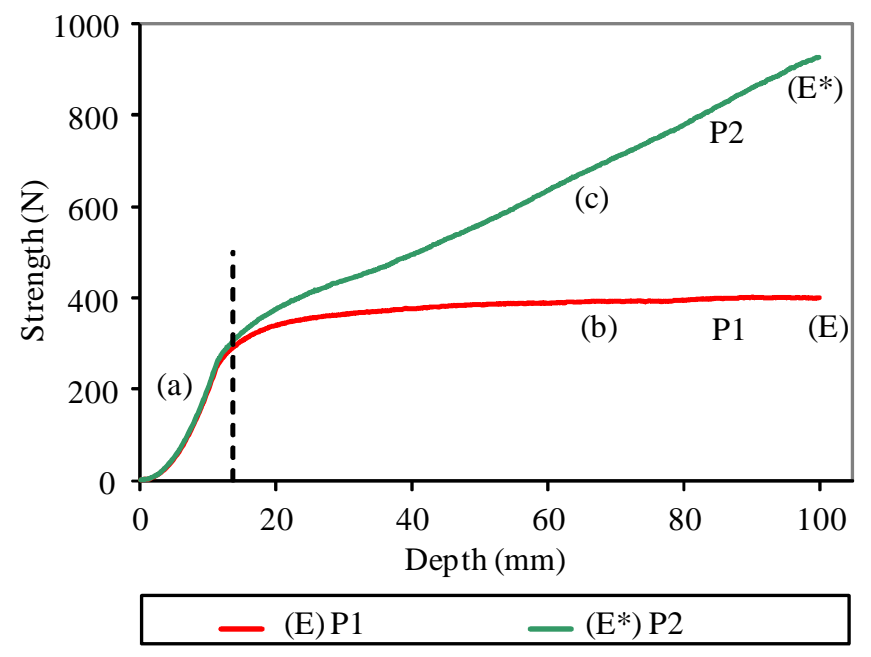

Figure 5: Total strength versus depth with P1 (E) and $\mathrm{P} 2\left(\mathrm{E}^{*}\right)$ probes.

\subsection{Coupled influence of water content and dry density at $20^{\circ} \mathrm{C}$}

This part presents the results of the tests carried out at $20^{\circ} \mathrm{C}$ on the samples described in Table 1.

\section{Cone tip resistance}

Figure 6 shows the evolution of P1 penetration strength for tests carried out in samples with different values of water content and dry density. The $b$ parts of the curves are constant indicating a good homogeneity of the samples. The maximal strength obtained during the tests increased with the decrease of the water content of the samples.

The samples E3 and E8 were prepared at the same initial dry density $\left(1.82 \mathrm{Mg} / \mathrm{m}^{3}\right)$. The difference of $750 \mathrm{~N}$ between the obtained strengths could be only due to the differences in water contents: for $\mathrm{E} 3, \mathrm{w}=$ $11.9 \%$ and for $\mathrm{E} 8, \mathrm{w}=15.1 \%$. Generally it could be noticed that the variation of the dry density has a lower impact on these results.

The Figure 7 superimposes the cone tip resistance at $90 \mathrm{~mm}$ penetration depth to the compaction curve. The lower the water content, the higher the tip resistance. On the other hand the decrease of the cone tip resistance is sharper at the dry side $(\mathrm{w}<14.5 \%$, equation 3 ) than the wet side ( $\mathrm{w}>14.5 \%$, equation 4 ). The equations of these two curves were defined in order to be used as a reference for the following tests.

$q_{c}=-2028.2 w+29770$

$q_{c}=49.589 w^{2}-1875.2 w+17919$

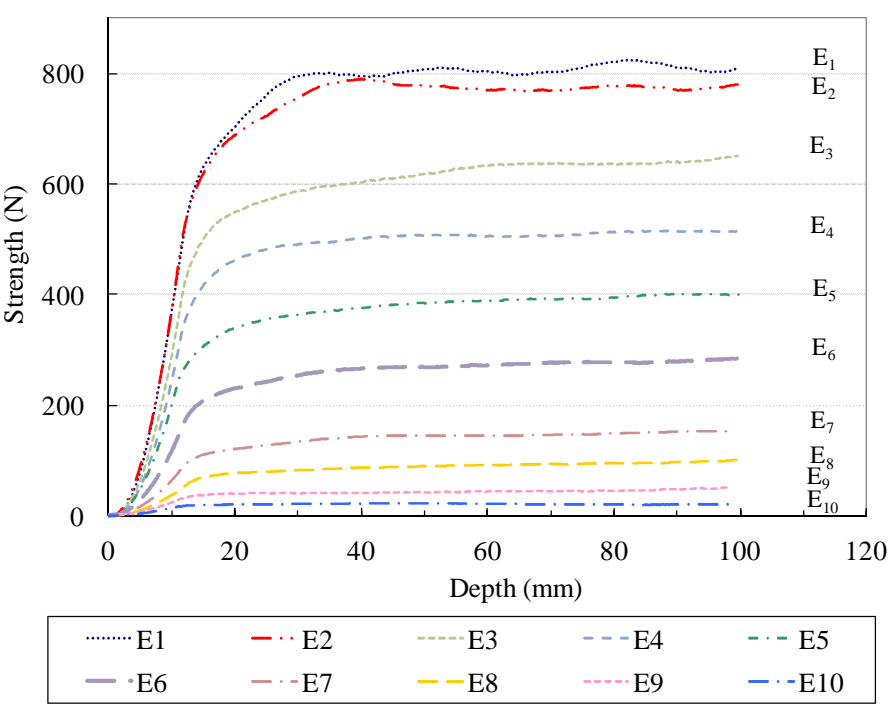

Figure 6: Strength measured along the penetration of $\mathrm{P} 1$ in samples at different water contents and dry densities.

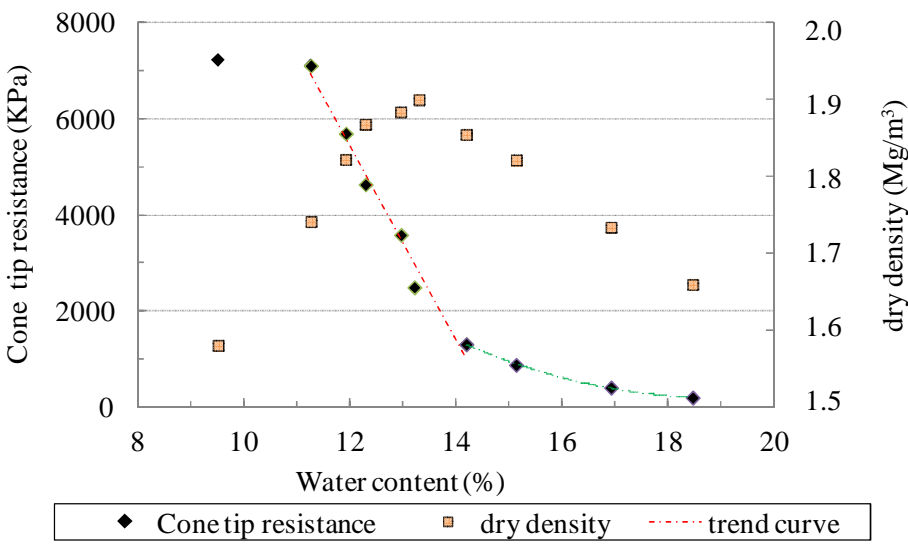

Figure 7: Comparison of the cone tip resistance at 90 $\mathrm{mm}$ penetration depth with the compaction curve

\section{Sleeve friction}

For each sample, a test with $\mathrm{P} 1$ and a test with $\mathrm{P} 2$ were performed. The difference between the two curves gave the sleeve friction (Figure 8). The comparison of sleeve friction at different couples of water content and dry density let us draw the same conclusion than for the cone tip resistance. The decrease of the water content of the samples increased the sleeve friction (Figure 9). The equations of the two curves for sleeve friction are showed in the equation 5 for water contents from $12 \%$ to $14.5 \%$ and in the equation 6 for water contents varying from $14.5 \%$ to 19.

$f_{s}=-74.353 w+1113.9$

$f s=1.5969 w^{2}-59.743 w+571.35$ 


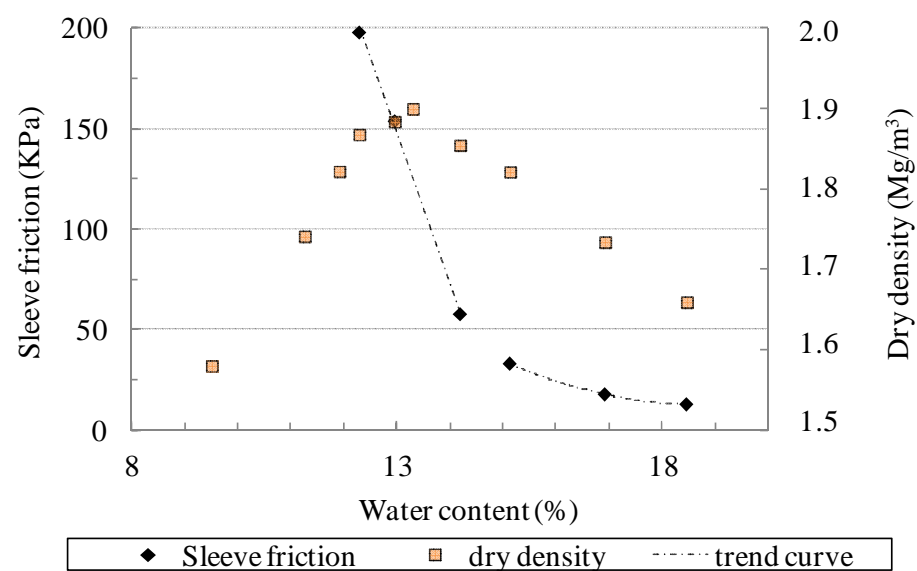

Figure 8: Sleeve friction calculated from the penetration tests with $\mathrm{P} 1$ and $\mathrm{P} 2$ at different water contents and dry densities

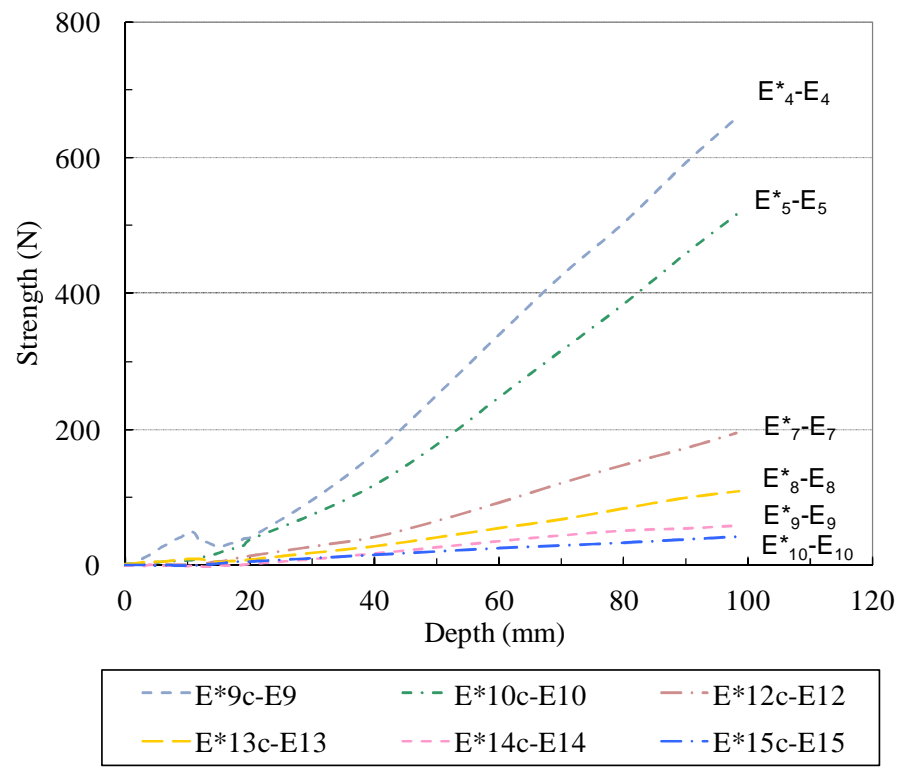

Figure 9: Comparison of the sleeve friction at $90 \mathrm{~mm}$ penetration depth with the compaction curve

\subsection{Impact of a thermal cure on the cone tip resistance and sleeve friction}

The results of penetration tests carried out on different samples (E11 to E13) after a thermal curing of 1, 30 , and $50^{\circ} \mathrm{C}$ were compared to the results of the same test at $20^{\circ} \mathrm{C}$ (E6) (See Table 1 and 3).

The cone tip resistance and the sleeve friction did not greatly change with the temperature variations between 1 to $30^{\circ} \mathrm{C}$. However an increase of the temperature to $50^{\circ} \mathrm{C}$, increased dramatically these two parameters (Figure 10). This phenomenon could be due to the fact that when heating the samples small water content changes occurred from $13.2 \%$ to $12.5 \%$ despite the complete covering of the mold during the thermal curing. As already shown in Figure 7 and Figure 9 (equation 3 and 5), this decrease in water content could increase dramatically both the cone tip resistance and sleeve friction.

Test E4 performed at $20^{\circ} \mathrm{C}$ on a sample with similar water content and dry density than E13, showed the same results (Table 3).

Table 3: Measured and theoretical cone tip resistance $\left(q_{c}\right)$ and sleeve friction $\left(f_{s}\right)$ at $90 \mathrm{~mm}$ penetration depth

\begin{tabular}{|l|l|l|l|l|}
\hline Sample number & E11 & E6 & E12 & E13 \\
\hline Temperature $\left({ }^{\circ} \mathrm{C}\right)$ & 1 & 20 & 30 & 50 \\
\hline$q_{c}(\mathrm{KPa})$ & 2323 & 2504 & 2336 & 4075 \\
\hline$f_{s}(\mathrm{KPa})$ & 105 & $131 *$ & 106 & 317 \\
\hline
\end{tabular}

$*$ Calculated with equation 5

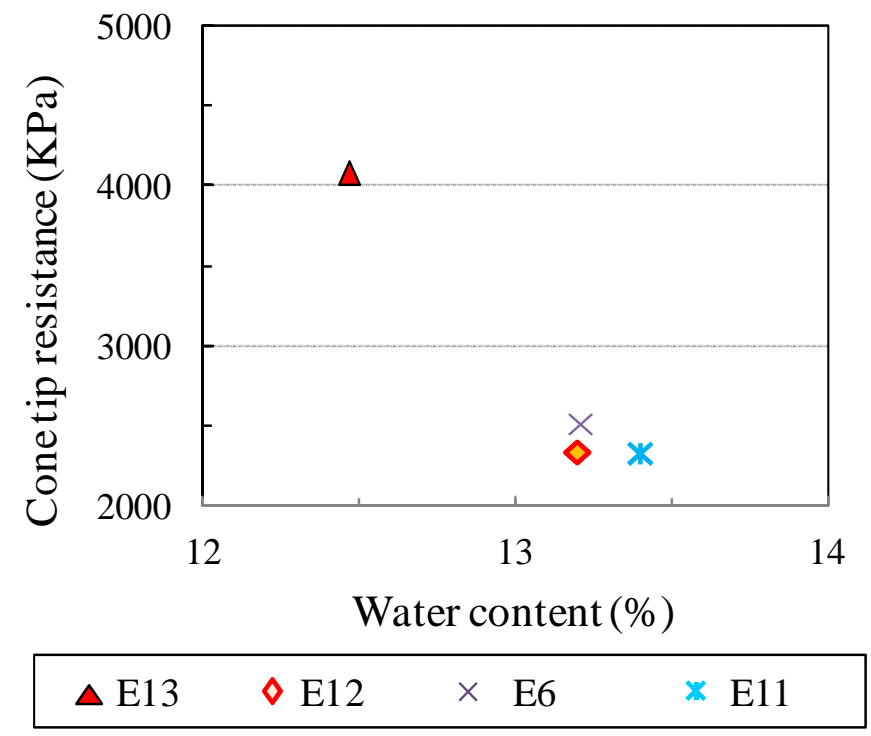

Figure 10: Comparison of cone tip resistance at 90 mm depth E11, E6, E12 and E13 respectively carried out at $1,20,30$ and $50^{\circ} \mathrm{C}$.

\section{CONCLUSION}

The purpose of the study was to develop a high resolution mini-penetration test to propose an easy-touse method to define quickly the influence of different temperatures on cone tip resistance $\left(q_{c}\right)$ and sleeve friction $(f s)$ of a soil. The results showed a good repeatability and reliability of the test.

The study was divided into several phases: (1) definition of an adapted compaction protocol, (2) definition of the thermal cure protocol, (3) definition of penetration test conditions (depth, velocity, ...).

The effects of water content and dry density and thermal cure on the penetration test parameters were studied.

We showed that the decrease of the water content of the samples increased the cone tip resistance and the sleeve friction. The variation of the dry density of the sample has a lower impact than the variation of its water content on the penetration parameters. The 
decrease of the cone tip resistance and the sleeve friction is nevertheless sharper at the dry side of the compaction curve $(w<14.5 \%$, equation 3$)$ than at the wet side (w>14.5\%, equation 4$)$.

The whole results let us conclude on the small influence of thermal cure between 1 and $30^{\circ} \mathrm{C}$ on penetration parameters for the mixture kaolinite/Hostun sand. Thermal curing at higher temperature $\left(50^{\circ} \mathrm{C}\right)$ lead to a decrease of the sample water content and, as a result, an increase in cone tip resistance and sleeve friction.

\section{BIBLIOGRAPHY}

Afnor. (1992). NF P11-300. Exécution des terrassements - Classification des matériaux utilisables dans le construction des remblais et couches de forme d'infrastructures routières. Association Française de Normalisation, Paris, France, 21p.

Afnor. (1993). NF P94-051. Sols: reconnaissance et essais; Détermination des limites d'Atterberg Limite de liquidité à la coupelle - Limite de plasticité au rouleau. Association Française de Normalisation, Paris, France, 15p.

Afnor, (1996). NF P94-113. Sols: reconnaissance et essais ; Essai de pénétration statique. Association Française de Normalisation, Paris, France, 16p.

Afnor. (1999). NF P94-093. Sols: reconnaissance et essais ; Détermination des références de compactage d'un matériau. Essai Proctor Normal. Essai Proctor Modifié. Association Française de Normalisation, Paris, France, 18p.

Brandl, H. (2006). Energy foundations and other thermo-active ground structures. Geotechnique 56/2, 81-122

De Bruyn, D., Thimus, J. F. (1996). The influence of temperature on mechanical characteristics of Boom clay: The results of an initial laboratory program. Engineering Geology, 41, 117-226.

Fromentin A., Pahud D., Laloui L., Moreni M. (1999) Pieux échangeurs : Conception et règles de pré-dimensionnement, Revue française de génie civil 3(6), 387-421.

Houston, S. L., Houston, W. N., Williams, N. D. (1985). Thermo-mechanical behavior of seafloor sediments. Journal of Geotechnical Engineering, 111(11), 1049-1263.

Hueckel, T., Baldi, G. (1990). Thermoplasticity of saturated clays: Experimental constitutive study. Journal of Geotechnical Engineering, 116(12), 17781796.

Kuntiwattanakul, P., Towhata, I., Ohishi, K., Seko, I. (1995). Temperature effects on undrained shear characteristics of clay. Soil and Foundations, 35(1), 147-162.

Laloui L, Moreni M, Vulliet L. (2003). Comportement d'un pieu bi-fonction, fondation et échangeur de chaleur. Canadian Geotechnical Journal 40(2), 388-402.

Lingnau B. E., Graham, J., Yarechewski, D., Tanaka, N., Gray, M. N. (1996). Effects of temperature on strength and compressibility of sand-bentonite buffer. Engineering Geology, 41, 103-115.

McCartney, J. S., LaHaise, D., LaHaise, T. Rosenberg, J. (2010). Application of Geoexchange Experience to Geothermal Foundations. Proceeding of The Art of Foundation Engineering practice, Geotechnical special publication 198, Hussein, M. H., Anderson, J. B. and Camp, W.M. editors : 411-423.

Mitchell J. K. (1964). Shearing resistance of soils as a rate process. Journal of the Soil Mechanics and Foundations Division, ASCE. 90, 29-61.

Noble, C. A., Demirel, T. (1969). Effect of temperature on strength behavior of cohesive soil. Dans Effects of Temperature and Heat on Engineering Behavior of Soils, Special report 103, Highway Research Board.

Peron H., Laloui L. (2011). A method for the geotechnical design of heat exchanger piles, Proceedings of the Geo-Frontiers Conference, ASCE Conf. Proc. doi:10.1061/41165(397) 49.

Sherif, M. A., Burrous C. M. (1969). Temperature effects on the unconfined shear strength of saturated, cohesive soil. Effects of Temperature and Heat on Engineering Behavior of Soils, Special report 103, Highway Research Board. p. 267-272.

Tanaka, N., Graham, J., Crilly, T. (1996). Stressstrain behaviour of reconstituted illitic clay at different temperatures. Engineering Geology, 47. 339-350.

Weibe, B., Graham, J., Tang, G. X., Dixon, D. (1998). Influence of pressure, saturation and temperature on the behaviour unsaturated sand-bentonite. Canadian Geotechnical Journal, 35, 194-205. 